\title{
IMPACT OF COVID-19 ON RURAL TOURISM IN NEPAL
}

\author{
Malati Kaini*
}

\begin{abstract}
This paper has focused upon the rural tourism in Nepal and the impacts of COVID-19 on its development. In Nepal tourism mostly occurs in rural environments and involves rural experiences. Wonderful rural cultures and traditional farming are attracting tourists in the rural areas. The villages of Nepal have their own unique natural and cultural dimensions. The fresh environment, natural and cultural artifacts, and the lifestyle of the local people are the main things to experience in the villages. Greatest potential benefit of rural tourism is its ability to generate money, which can translate into numerous positive economic opportunities for locals and their communities. But the COVID-19 pandemic has had a significant adverse impact on most businesses including rural tourism. Before COVID-19, rural tourism had become one of the most important activities to generate income in some rural areas of Nepal. But now all activities of rural tourism are in coma. Thus, in the post COVID-19 scenario, the very survival of the rural tourism industry will become the biggest challenge because there was no specific preparedness strategy in case of any crisis of this scale. Some measures are suggested to address the challenges and help prepare the strategy.
\end{abstract}

Keywords: active, economically, good, homeland, impact, rural, tourism

\section{Introduction}

Nepal with rich ancient cultures and natural beauties is a land of discovery and unique experience. That is why, tourism has become one of the mainstay of Nepalese economy. It is also a major source of foreign exchange and revenue. In Nepal tourism mostly occurs in rural environments and involves rural experiences. Rural tourism can be termed as any form of tourism that showcases the rural life, art, culture and heritage at rural locations, thereby benefiting the local community economically and socially. In this tourism process, moving of people outside their house towards rural areas takes place for the purpose of viewing rural beauty, gaining knowledge upon rural culture, farming activities, viewing and photographing natural beauties through rural open land areas. It leads to all tourism activities taking place in the rural areas and involves the movement of people to rural areas

* Mrs. Kaini is a faculty member of Rural Development, Patan Multiple Campus, TU, Nepal 
for a minimum timing of 24 hours to maximum 6 months for the purpose of leisure, learning more about rural areas activities and pleasure. At present, the contribution of tourism to the GDP of Nepal is $7.9 \%(\mathrm{GoN}, 2019)$ and the share of rural tourism in this contribution is significant.

We all know that Nepal is rich in natural beauty with good aspects of tourists' hospitable entry within rural areas. Wonderful rural cultures, traditional agricultural practices are always warmly welcoming tourists inside the concerned rural areas. Inside the world's arena Nepal lies under one of the best tourist destination. Hence, different places (mainly rural areas) of our country are turning to tourist centers in the name of rural tourism. Mostly rural communities are working out cooperatively for saving their own culture through residing different ethnic groups in a traditional way. All the active rural population are working closely for showing own conserved local activities and laid natural beauties to the domestic and international tourists. Economic life of rural people was improving through such activities but boring part happened after the unwanted hit by corona virus pandemic (COVID-19) from 31 December 2019 to the world including Nepal.

\section{Objective}

The main objective of this paper is to review the impact of COVID-19 on tourism and then suggest ways of rural development through rural tourism for the post COVID-19 pandemic era.

\section{Methodology}

In this paper a review work has been conducted upon the impact of COVID-19 on tourism particularly in the rural areas of Nepal. Being a review paper, methodologically secondary sources of information through the documents from Government and Non-government organizations, Nepal Tourism Development Board, Central Bureau of Statistics and so on are applied.

\section{Results and Discussion}

\section{Rural tourism}

Rural Development is a subset of the broader term "Development". This word rural development connotes overall development of rural areas with a view to improve the quality of life of rural people. According to Robert Chambers (1983), "Rural Development is a strategy to enable specific group of people, poor rural women and men, to gain for themselves and their children more of what they want and need". Out of 460 rural municipalities (GoN, 2015), mostly all the rural areas are very much attractive for making 
rural tourism as the successful venture. Hence, the rural areas of Nepal should get priority in rural tourism for developing ruralareas in a sustainable way.

All the rural municipalities and village councils are having attractive hotspots for the attracting tourists (both domestic and international tourists). Furthermore, the local people of all the rural municipalities are interested to use their local resources (natural and manmade traditional ones) for the attraction and good entry of tourists. Some of the types of rural tourism for attracting domestic and international tourists are mentioned in the following table;

Table no. 1: Types of Rural Tourism

\begin{tabular}{|l|l|}
\hline \multicolumn{2}{|c|}{ Types of Rural Tourism } \\
\hline Ecotourism & Adventure tourism \\
\hline $\begin{array}{l}\text { Cultural and Religious } \\
\text { Tourism }\end{array}$ & Health tourism \\
\hline Agro-tourism & Sports tourism \\
\hline Recreational tourism & $\begin{array}{l}\text { Business and Conference } \\
\text { tourism }\end{array}$ \\
\hline
\end{tabular}

Source: Gautam, 2007

The villages of Nepal have their own unique natural and cultural dimensions. The fresh environment, natural and cultural artifacts, and the lifestyle of the local people are the main things to experience in villages. The local attractions, scenic beauty, agricultural fields and terraces, the lifestyle of the local people are the main things to explore in village. The concept is niche but is educational and interesting. The local foods, local lifestyle and to live like locals is the most interesting part of rural tourism in Nepal. The idea behind rural tourism is not only beneficial and informative to tourists, but it also helps to enhance the economic standard and lifestyle of local people.

Greatest potential benefit of rural tourism is its ability to generate money, which can translate into numerous positive economic opportunities for locals and their communities. For locals the first benefit of tourism development is jobs within the tourism sectors and outside of it. Tourism development means more income and profits for tourists' related business. The economic multiplier model suggests that if local income from tourist expenditures is spent within local area, an increase in local income $\&$ jobs will follow.

\section{The following points highlight the significance of rural tourism in Nepal;}

The concept of rural tourism is definitely helpful \& effective for Nepal where a hospitable population lives in villages. Different villages have different types of tourism resources, 
which is scattered, in the entire state. Rural tourism can check and stop the flow of people to migrate in cities. The gradual expansions of cities and urbanizations some time allures the people to migrate from rural to urban areas. Rural tourism can be one of the important aspects, which can provide a solution to this problem.

Sometimes rural economy adversely affected due to the increase in input costs and decrease in income. Number of debt-ridden farmers forced to commit suicides. Systematic efforts to promote rural tourism as a subsidiary occupation can attract this trend with balanced regional development.

A notable advantage of Rural Tourism compared to other types of economic activity for combating rural poverty is that as the consumer travels to a rural destination, there exists an opportunity for a direct economic linkage between the tourist and the rural poor, forexample, through the selling and buying of handicrafts. (Handicrafts village, Shilpagram, Rural Hat, etc.).

Small-scale enterprise development aided by micro- finance schemes has a significant potential for enhancements of rural livelihood opportunities.

This concept has the tremendous potentiality to attract the investors in rural areas (Farm house, Agro based Industry, Organic fertilizer \& rural development schemes). Followings will be there;

- $\quad$ Promotion of harmony \& understanding

- $\quad$ Restoration of Culture

- $\quad$ Environmental preservation

- $\quad$ Community development

\section{Impact of the COVID-19 pandemic on rural tourism}

The infectious disease caused by a novel form of coronavirus (SARS-CoV-2) was first detected in December 2019. The outbreak was declared a Public Health Emergency of International Concern on 30 January 2020. Nearly a third of the world's population are now living under coronavirus-related restrictions. The coronavirus (COVID-19) pandemic is the defining global health crisis of the present century. Since its emergence in last week of December, 2019, the virus has spread to every continent except Antarctica. It spread across the globe very fast, and affected millions of people. It has so far devastated more than 200 countries. Cases are rising daily in Africa and South America, and Europe and USA were taken over as the epicenters of the disease for the first wave and South Asian countries particularly India and Nepal for the second wave. More cases are now being reported every day. 
The pandemic is moving like a wave- one that may yet crash on those least able to cope. It took 67 days to reach the first 100,000 confirmed cases worldwide, 11 days for this to increase to 200,000 and just four to reach 300,000 confirmed cases. Each person with Covid-19 transmits coronavirus on average to two to three people. With such a large multiplying factor, there will be exponential growth of cases. If there are 100 cases today, there will be 200 in a couple of days and a thousand in over a week. If contact tracing and isolation measures are not strictly instituted, this number could spiral to a million in a month, which would be disastrous in a country like Nepal.

In Nepal, the first case was confirmed on 24 January 2020. Most of those who were tested positive were returnees from a neighboring country. Later on, the virus was spread in the community and people from different sphere were affected. For example, four federal ministers, some MPs and political leaders of major political parties including former king and queen, and former Prime Minister Dr. Baburam Bhattarai, many doctors and health workers, and thousands of security personnel were contracted the virus. This indicates the severity of the situation.

\section{Relevancy of this statement is;}

The second wave of COVID-19 started to hit India from mid-March 2021 and increased rapidly, reaching a peak of more than 400,000 recorded daily cases on 30 April. Many Nepalese were working in different parts of India. When they returned to Nepal, and went through the PCR test for the disease, most of them tested positive. Due to the porous border, many entered Nepal without PCR tests. By the end of March 2021, only about 150 new infections were appearing daily in Nepal. Until the first half of April, daily trials were minimal, and daily infections and deaths remained normal. After then, daily infections and deaths started to rise sharply. On 9th May 2021, the country crossed the previous mark of the highest single-day cases - 5,743 - recorded on October 21, 2020 with a record singleday cases of more than 9000.Apparently, the infections were spreading very fast during this second wave as compared to the first wave.

Nepal has reached a position where the daily positivity is very high not only in this region but also in the world. Past experience and inability to learn from the rest of the world was the biggest weakness and mistake of Nepal. As the situation with the second wave of COVID-19 became very deadly and alarming, the prime minister of Nepal requested the international community for help.

A study of nearly 700 enterprises in 52 of the 77 districts, conducted by the central bank in June, 2020 showed most jobs lost in hotels and restaurants followed by agriculture, forestry, rural tourism, and the wholesale and retail sectors. Similarly, an ILO study said that the 
COVID-19 disrupted the education of more than 70 percent of youth, leaving a disproportionate effect on young people (ILO, 2020). Hence, the impacts of COVID-19 in daily life are extensive and have far reaching consequences. These can be divided into various categories. The economic consequence has become visible through

- slowing of the manufacturing of essential goods;

- disrupting the supply chain of products;

- losses in national and international business;

- poor cash flow in the market; and

- significant slowing down in the revenue growth

\section{Effect in the rural tourism}

COVID-19 pandemic has caused widespread disruption in socio-economic activities including the tourism sector. Several countries in the world including Nepal has imposed travel restriction and lockdown to combat COVID-19. Thus the COVID-19 pandemic has had a significant adverse impact on most businesses including rural tourism. According to the Journal of Tourism and Adventure, the pandemic has adversely affected every subsector of the tourism industry in Nepal after imposition of the lockdown.

Nepal has been a popular destination for tourists specifically from countries like China, India, and the USA with an annual flow of tourists more than a million. As seen from the available data, the number of tourists from these countries drastically decreased after the outbreak of the COVID-19 pandemic.

A lockdown, which is an emergency protocol that requires all to stay at home, is one of the possible options to control the spread of COVID-19. Realizing this fact, Nepal had announced a lockdown across the country from 24 March. During the first wave period, the government extended lockdown up to 5th times. During second wave period, inhibitory orders were imposed.

But the lockdown and inhibitory orders hurt marginalized communities due to loss of livelihood and lack of food, shelter, health, and other basic needs. The government did have a responsibility to protect the health and well-being of these population. The blanket closing of state borders without preparation caused disruption in the supply of essential goods, leading to inflation and fear of shortages.Thousands of such poor people were in need of protection. The Government of Nepal was facing an extraordinary challenge to protect them. All necessary steps were needed to be taken to ensure that everyone had access to food and medical care, and that the poor and marginalized were not mistreated or stigmatized. 
Before COVID-19, rural tourism had become one of the most important activities to generate income in some rural areas of Nepal. But now all activities of rural tourism are in comma. Thus, in the post COVID-19 scenario, the very survival of the rural tourism industry will become the biggest challenge, particularly because there was no specific preparedness strategy in case of any crisis of this scale. This gap is something that we need to pay heed to the sector. The following measures are suggested to address the challenges: 1) The concept of Restart, Revive and Rethink can be streamlined for sustaining and streaming tourism in new normal.

2) Development of health and hygiene protocol and strong monitoring together with effective tourism guidelines can give immediate direction to restart.

3) Similarly, a public private collaborative approach for tourism resilient building and preparedness for future possible crisis management should be the prime concern of the sensitive tourism industry.

4) Accordingly, investment on nature-based solutions can have potentials to drive innovation in rural tourism mitigating the environmental impact in tourism activities and development interventions, which ultimately results into sustainable natural resource management and conservation.

5) Also, contribution of the value of revenue generated as an ecotourism service at destination level could enable the tourism sector to capitalize ultimately to enable sustainable recovery.

6) Moreover, a transformational stage can be envisioned in the post COVID-19 era, where destination management organizations and policy makers can lead this crisis as an opportunity to rethink the future course of sustainable tourism.

7) Travelers will be looking for secluded places of incredible natural beauty. In this regard, Nepal should initiate to develop Hill-Stations. This has two-fold approaches. Firstly, it will add on to new products and will showcase to travelers. Secondly, it will address the major issue that Nepal is currently facing- a destination for a limited period. Nepal needs to change itself from a destination for a limited season to a destination that is a Reason for All Seasons. This will not only help to change the brand image of Nepal that is perceived as a country only for mountaineering and trekking, but will also help to provide immersive experiences that are based on nature-based tourism engaging with locals and taking in new experiences. 


\section{Conclusion}

Nepal is having great potential for development through rural tourism. All the provinces are having very nice rural areas for developing rural tourism. Due to the cause of this corona pandemic, currently thousands of Nepali working abroad and India have returned home and they are now jobless. Most of them are now free of corona virus and they can play important roles for the economic development of the country through rural tourism. In postCOVID-19 tourism, travelers will embark on a journey to an exotic location; will seek out the less crowded places. Visitors will be preferring destinations which are away from the hustle bustle of cities.

Furthermore, many rural areas in the Mid-Hills of Nepal are culturally rich and feasible for all seasons both for domestic and international tourists. Climate and accessibility wise MidHill regions are also well-suited for travelling and livelihoods as this falls under $2000 \mathrm{~m}$. In most of the years, the regions are mostly sunny, with breathtaking landscapes, views and greenery in the surrounding areas. Yoga, meditation, organic foods, agro-tourism, wilderness, local people and culture are some of the potential activities that can be introduced for developing rural tourism in the mid-hills regions.

Proper utilization of beautiful natural resources will help people to develop their areas. Furthermore, these phenomena will certainly help the people for being self-reliance through conserving the local resources and utilizing theme for economic purposes. This type of model of economy will attract more young people to stay in their villages, resulting in reduced out-migration. Our young people will not have to face the problems of employment in future as they are facing now.

\section{References}

Dhakal, R. (2015). Overview of Tourism Development prospects in Nepal. Kerava: KeravaLaurea University of Applied Sciences.

Gautam, B. P. (2007). Tourism and Economic Growth in Nepal, Doctor of Philosophy, Udaipur College. Udaipur, India: Udaipur College.

Gautam, B. P. (2011). Tourism and Economic Growth in Nepal. NRB Economic Review, 1-13. Nepal Rastra Bank, Research Department. Kathmandu, Nepal: Nepal Rastra Bank.

Gilbert, D. (1989). Rural Tourism and Marketing: Synthesis and New Ways of Working. Tourism Management, 10(1), 39-50.

GoN (Government of Nepal). (2015). Constitution of Nepal. Singhdurbar, Kathmandu: Government of Nepal. 
GoN (Government of Nepal). (2019). Economic Survey, National Planning Commission Secretariat. Kathmandu: Central Bureau of Statistics.

GoN (Government of Nepal). (2021). Economic Survey, National Planning Commission Secretariat. Kathmandu: Central Bureau of Statistics.

GoN (Government of Nepal). (2010). Homestay Running Policy 2010, Tourism Management Division. Kathmandu: Ministry of Tourism and Civil Aviation.

GoN (Government of Nepal). (2019). 15 ${ }^{\text {th }}$ Plan Approach Paper. Kathmandu: National Planning Commission.

ILO (International Labour Organization). (2020). COVID-19 disrupts education of more than 70 per cent of youth. Retrieved from https://www.ilo.org > news > WCMS 753060 > lang_en.

NepaliSansar. (2019). Nepal Tourism Industry: USD 2.1 Bn Revenue, 1 Mn Jobs. Retrieved from www.nepalisansar.com > tourism > nepal-tourism-industry.

Singh, K. (1999). Concepts and Connotations of Rural Development. In Rural Development Principles, Policies and Management ( $2^{\text {nd }}$ ed.). (20). New Delhi: Vistaar Publications.

UNWTO (United Nations World Tourism Organization). (2017). Tourism and Culture. 22nd Session of the General Assembly. China: Chengdu.

WDA (World Data Atlas). (2018). Nepal - Contribution of travel and tourism to GDP as a share of GDP. World Data Atlas.

Worldometer. (2021). COVID-19 CORONAVIRUS PANDEMIC. Retrieved from www.worldometers.info $>$ coronavirus. 